\title{
ENSAIO SOBRE O TEMPO NOS CONTRATOS DE CONSUMO*
}

\section{Gilles Paisant**}

1 - Assim como em todas as esferas humanas, o tempo exerce sua influência em todos os domínios do direito ${ }^{1}$. Uma vez que a ele compete, de maneira recorrente, responder a questões tais como: Quando? Durante ou após quanto tempo? ou até quando?, reservase ao direito a tarefa de se preocupar com as questões de datas, durações e prazos.

Por exemplo, a ele compete se pronunciar a respeito da data de entrada em vigor da nova lei ou sob a qual deve-se cumprir tal ou qual obrigação, bem como a duração de um compromisso, de uma sanção ou de uma prerrogativa a ser determinada; ou ainda, será indispensável a fixação de prazos para agir ou reagir... De acordo com o caso, o tempo regerá os direitos ou obrigações. Trata-se de uma ferramenta disponível ao legislador, que presumese na posição de utilizá-la da maneira mais conveniente possível. Ainda que o tempo transcorra de forma semelhante para todos, nem por isso representará o mesmo valor jurídico para todos. O uso do tempo pelo direito constitui um meio dentre outros para se atingir um fim.

2 - Essas considerações valem igualmente para o domínio contratual, já que, não somente em razão do contrato figurar no tempo, mas também porque o tempo pode ser um recurso contratual.

Primeiramente, com efeito, é o processo de formação do contrato que pode ser escalonado no tempo, pois que, por exemplo, o encontro de vontades necessita uma fase prévia mais ou menos extensa de debates, ou ainda, haja vista que a conclusão do acordo final antecede a de um contrato preliminar, tal qual uma promessa de contratar.

Mas o tempo é igualmente convocado a desempenhar um grande papel na execução dos contratos.

Ainda que não expressamente formulado pelo Código Civil, a distinção dos contratos de execução instantânea e execução sucessiva pode, com efeito, ser considerada como tradicional ${ }^{2}$. Contrariamente aos primeiros, cuja execução se perfaz em uma prestação vencida, os últimos visualizam sua execução se propagar no tempo.

Todavia, essa distinção não deve induzir a erro, tampouco levar a crer que somente os contratos de execução sucessiva ou escalonada ${ }^{3}$ são sensíveis ao fator tempo, ao se apoiarem na duração ${ }^{4}$. A prestação única do contrato de execução instantânea pode, efetivamente,

\footnotetext{
* Artigo originalmente publicado em Études offertes au Doyen Pbilippe Simler, Litec-Dalloz, 2006. Tradução livre e autorizada de Carolina Paranhos Coelho, Carolina Moreira, Joyce Copstein Wainberg e Luiz Gustavo Meira Moser, integrantes do Grupo de Pesquisa CNPq "Mercosul e Direito do Consumidor", sob a coordenação da Prof. ${ }^{2}$ Dr. ${ }^{2}$ Claudia Lima Marques.

** Professor da Faculdade de Direito e de Economia de Chambéry - França.

1 Cf por ex : P. HÉBRAUD, Obserations sur la notion de temps dans lè droit cizili in Mélanges P Kayser, t. II, 1979, P- 1 et s. ;A. BRTMO, Réflexions sur le temps dans la théonie générale du droit et de l'Etat: in Mélanges P Hébraud, 1981, p. 14 5; S. GuiNCHARD, Le temps em procédure cizile An > Fo Droit Clemont 1983, p. 21; - M CouLON et A - M.FRISON-ROCHE (dir.), Le temps dans la procedure, Dailoz, 1996

2 F. TERRÉ, P. SIMLER, Y. LEQUETTE, Les obligations, $9^{\circ}$ éd., Dalloz, 2005, $\mathrm{n}^{\circ} 70$

3 A respeito dessa noção, cf. M.- L. CROS, Les contrats à execution échelonnée : D 1989, chron. 49

4 J.AZÉMA, La dunée des contrats successifs, L G D I, 1969.
} 
demandar algum tempo, o mesmo vale para o caso da realização de uma obra complexa, na redação de um livro ou manual. Ela pode também ser diferida no tempo pois que, por exemplo, o bem adquirido não sendo disponível no momento do intercâmbio de consentimentos, convencionou-se um prazo de entrega.

Mais concretamente, o tempo será com frequência utilizado para modelar as obrigações das partes, assim como para determinar a duração do vínculo ou ainda o prazo para cumprilo. Nesse tocante, num sistema de liberdade contratual, no qual cada um discute em pé de igualdade seus interesses, a arma do tempo é neutra: ela não favorece apriori um contratante em detrimento de outro. Cada um busca utilizá-lo na forma que mais lhe convier.

O Código Civil intervém, em diversas ocasiões, para regular o uso do tempo pelos contratantes. Por exemplo, os artigos 1709, 1780, 1838 e 2004, os quais, em matéria de arrendamento, aluguel de obra, de sociedade e mandato, se opõem aos vínculos perpétuos, são geralmente interpretados como complementares para estampar um princípio geral de proibição nesse domínio ${ }^{5}$. Ou ainda, com o advento de uma recente reforma relativa aos contratos eletrônicos, exige-se que o autor da oferta acuse a recepção "sem prazo injustificado" do pedido que the foi endereçado 6 . Contudo, via de regra, mesmo que se vislumbre as consequiências do atraso, por uma das partes, na execução de suas obrigações ${ }^{7}$, o Código não inviabiliza os rearranjos contratuais, em observância à liberdade contratual.

3 - Pelo contrário, em virtude das necessidades de proteção aos consumidores, a visão do tempo veiculada pelo Código do Consumidor é fundamentalmente dirigista ${ }^{8}$.

Assim como a liberdade contratual, o tempo não deve constituir uma arma à disposição do mais forte, o profissional, em detrimento do mais fraco, o consumidor?. Deve-se, pelo contrário, servir de instrumento para o estabelecimento de um equilíbrio efetivo na relação contratual entre ambos. Para atingir tal fim, a lei atribui de forma rasa a vantagem do tempo ao mais fraco (I) enquanto que, de maneira complementar, ela tende a restringi-la para o mais forte (II).

\section{I - A vantagem do tempo para o consumidor}

4 - Essa vantagem se manifesta em numerosas oportunidades no Código do Consumidor, em todas as etapas da vida do contrato entabulado entre o profissional e o consumidor; seja quando de sua conclusão ou na ocasião de sua execução, ou ainda para determinar a duração. Nessas diferentes circunstâncias, parece-nos que a preocupação do legislador é dúplice: por um lado, a preocupação da necessidade do tempo experimentada pelo consumidor (A) e, por outro lado, reconhece-lhe um certo domínio da duração da relação contratual (B).

\footnotetext{
Comp. J. GHESTIN, Existe-t-il em droit positif frangais um principe de probibition des contrats perpétuels ?: in Mélanges D. Talion, 1999 , p. 250 et s.

C. civ., art. 1369-5 résultant de lòrdonnance n ${ }^{\circ} 2005-674$ du 16 juin 2004

Por ex. C. civ., art. 1147,1153 ets s, 1229,1610,1611

8 Ordem pública de direção e ordem pública de proteção convergem para a mesma matéria. A regulação pela qual se viabiliza a proteção do consumidor corresponde, com efeito, às utilidade sociais do momento ao qual as atividades contratuais devem notadamente sujeitar-se

9 V.O. LITTY, Inégalité des parties et durée du contrat, L G D J $1999, \mathrm{n}^{\circ} 7$
} 


\section{A - O tempo atribuído ao consumidor}

5 - Parece-nos que o consumidor carecia de tempo em cada extremidade da relação contratual: primeiramente, do tempo para expressar um consentimento razoável face aos questionamentos, por vezes urgentes ou complexos, de profissionais, quiçá para resistir a seus próprios impulsos; tempo também para, eventualmente, estabelecer seus vínculos em relação ao profissional, ou seja, para perfectibilizar o pagamento do preço da prestação do serviço ou do bem fornecido.

\section{1) Para vincular-se}

6 - Quando da conclusão do contrato, parece-nos essencial nos dias de hoje a proteção específica ao consentimento da parte mais fraca, a despeito das condições requeridas pelo artigo 1108 do Código Civil. Se sabemos que o Código do Consumidor vincula-se ao fato de que, por meio de diversas obrigações e informações atribuídas aos profissionais, o consumidor estará na posição de expressar um consentimento claro, cuida-se de adicionar a esta urgência de transparência ${ }^{10}$ a necessidade de um consentimento ventilado, que permita ao consumidor o tempo de apreciar a oportunidade de seu vínculo.

Essa proteção do consumidor pelo tempo que lhe é atribuído para assimilar as informações a ele confiadas, e para se decidir, não resulta de um princípio geral formalmente exposto no Código do Consumidor. Ela é, no entanto, reveladora de uma tendência geral que se externaliza em diversas ocasiões, de duas maneiras complementares: o prazo de reflexão e o prazo de arrependimento.

7 - Em primeiro lugar, ocorre que a lei retarda o momento da conclusão do contrato ao permitir o aceite do consumidor somente após transcorrido o tempo de reflexão. Essa técnica é bastante salutar posto que obriga o consumidor, por sua própria proteção, a valerse do lapso temporal antes de se vincular à oferta do profissional.

8 - É assim que o artigo L. 312-10 do Código do Consumidor dispõe a respeito do crédito imobiliário ao consumo: "o tomador e os fiadores não podem aceitar a oferta antes de dez dias após o seu recebimento" ${ }^{11}$. E, na ocorrência, uma atenção toda particular é destinada à efetividade dessa regra. Primeiramente, para evitar as práticas de contratos sem data, a lei atribui uma dupla precaução: não somente o profissional deve endereçar sua oferta pela via postal ${ }^{12}$, mas também a aceitação do consumidor, sendo emitida nas mesmas condições ${ }^{13}$, deve-se coletar o carimbo postal nos dois casos ${ }^{14}$. Ademais, a Corte de Cassação considera que essas disposições, de ordem pública, são irrenunciáveis ${ }^{15}$, e a irregularidade de

10 G. PAISANT, De lobligation de transparence dans les contrats de consommation : in Mélanges Roger Decottignies, P U G, 2003, p. 233 et s.

11 Artigo L. 312-27 contém disposições análogas no caso de locação-venda imobiliária e de locação acompanhada de promessa de compra e venda

12 Código do Consumidor., art L.312-7, al. 1".

13 Código do Consumidor., art L. 312-10, al 2.

14 Cf. todavia, Cass, 1er civ., 5 de julho de 2005 , recurso n ${ }^{\circ}$ 02-18907, inédito, versando que "a aceitação da oferta deve ser realizada por escrito com recibo datado".

15 Cass. 1" civ., 9 de dezembro de 1997 : Bull Civ.1, 1 368; Contracts, conc, consom. 1998, n 53, obs. RAYMOND; JCP 1998,II, 10148, nota PIEDELIEVRE 
aceitação realizada em prazo inferior a dez dias após a recepção da oferta, não pode ser albergada por uma ratificação ${ }^{16}$. Esses princípios não representam, todavia, obstáculo ao tomador, já que lhe é facultado reiterar sua aceitação posteriormente à expiração do referido prazo, notadamente via ato autenticado e reputado como nova aceitação ${ }^{17}$.

As sanções de desrespeito às disposições do artigo L. 3210-10 são governadas por uma sutil distinção perfeitamente externalizada no acórdão da $1^{\text {a }}$ Câmara Cível da Corte de Cassação de 12 de julho de $2005^{18}$ : enquanto que "a inobservância a regras de forma relativas às modalidades de aceitação da oferta de empréstimo imobiliário ${ }^{19}$ é sancionada pela decadência do direito a juros ${ }^{20}$, o desconhecimento do prazo de aceitação de dez anos enseja uma nulidade relativa que prescreve em cinco anos a contar da aceitação da oferta, a qual deve ser perfectibilizada via carta, com o carimbo postal empunhando a data de aceitação". Sabemos que, todavia, nesse último caso e até o presente, a Corte de Cassação considera que esse prazo legal de reflexão representa uma regra protetora de um interesse privado, o qual somente pode ser invocado pela pessoa eleita a receber a proteção ${ }^{21}$ para recusar o poder de ofício do juiz na matéria. Ademais, ao consumidor não será possível invocar a exceção de nulidade do contrato após o reembolso das primeiras trocas, pois a Corte de Cassação considera que essa exceção " pode ser impetrada apenas para macular o pleito de execução de um ato jurídico que ainda não foi perfectibilizado" "22.

Nessas condições, no afã de reforçar a eficácia do sistema, podemos questionar se, de lege ferenda, não seria oportuno, em todos os casos de desrespeito pelo estabelecimento de crédito de obrigações que a lei lhe impõe relativamente aos consumidores, de oferecer a estes, segundo seus interesses, a escolha entre a nulidade do contrato e a decadência do direito aos juros.

Em qualquer hipótese, essas sanções cíveis são reforçadas por um dispositivo penal. O profissional incorre em multa de 3.000 euros em dois casos : primeiramente, quando, para fazer crer que a aceitação foi dada no prazo legal, ele emite uma oferta não datada ou veiculando uma data incorreta ${ }^{23}$; em seguida, quando o profissional aceita receber, sob uma forma ou outra, uma quantia de dinheiro a título de operação de crédito antes da expiração do prazo da reflexão de dez dias ${ }^{24}$. Não se deve, com efeito, fazer com que o consumidor possa se sentir vinculado pelos pagamentos prematuros. Essas sanções penais parecem, contudo, menos danosas que a decadência do direito a juros.

\footnotetext{
16 Cass. 1 er civ, 18 de janeiro de 2000 : Contrats, conc, consom. 2000, n 117, obs. RAYMOND.

17 Cass. 1 er civ, 19 de maio de 1999 : Bull. Civ. I, n० 167 - 18 de janeiro de 2000, préc -2 de novembro de 2005, recurso n 03 20918, inédito; comp. em sentido contrátio, Cass. Ier civ., 30 de março de 1994 : Bull. Civ. I, n 130; Contrats, conc, consom. 1994, n'129, obs. RAYMOND; Defrénois 1994, 1476, obs. D. MAZEAUD.

18 Recurso $n^{\circ} 02-13614$, inédito.

19 Ou seja, uma aceitação que será extemada diferentemente do que via carta remetida.

20 Código do Consumidor, art. L. 312-33

21 Cass. 1 er civ., 27 de fevereiro de 2001 : Bull. Civ. I, $n^{\circ} 48 .-9$ juill $2003:$ Bull. Civ. I, $n^{\circ} 170$.

22 Cass. 1 er civ., 3 de julho de 2001 : Bull civ. I, n ${ }^{\circ} 201$

${ }^{23}$ Código do Consumidor., art. L. 312-33. at. 2 et 3

24 Código do Consumidor, art L. 3122-34.
} 
9 - Ainda que situado fora do Código do Consumidor, mas respondendo as mesmas preocupações, convém igualmente citar o caso dos contratos entabulados com estabelecimentos privados, cujo objeto é o ensino à distância. Na ocorrência, é oferecido ao consumidor um prazo de reflexão mais exíguo, sob pena, aqui também, de nulidade do contrato. ${ }^{25}$

O artigo L. 444-8 do Código de Educação prevê, com efeito, que um tal contrato "somente pode ser assinado transcorrido um prazo de sete dias após sua recepção". E, para assegurar a observância a essa exigência, um decreto confirma que tanto o projeto de contrato quanto o próprio contrato, uma vez assinado pelo consumidor, deve ser endereçado ao destinatário via carta com aviso de recebimento ${ }^{26}$.

Aqui também um dispositivo penal corrobora a proteção ao consumidor, mas sem ser específico quanto ao desrespeito ao prazo de reflexão, vez que é todo infração a dispositivos da lei relativa a esse tipo de contrato que é " possível de um ano de prisão e 1.500 euros de multa ${ }^{27}$.

10 - Em segundo lugar, de maneira bastante usual, o tempo atribuído ao consumidor no momento da conclusão do contrato transforma-se em prazo de arrependimento ou de retratação ${ }^{28}$. Nessas circunstâncias, durante um período determinado após a imediata assinatura do contrato, a lei confia ao consumidor o direito unilateral de retomar seu compromisso, no entanto, regularmente externado. Podemos analisá-lo como uma faculdade da retratação legal 29. Trata-se, portanto, de uma "reflexão a posterion" ${ }^{30}$ confiado ao consumidor que, seduzido pela oferta do profissional, não terá tido tempo de apreciar a real oportunidade, nem a de dimensionar a exata vinculação de seu aceitação. De maneira perfeitamente realista, o legislador pensa, nessas ocorrências, em certas práticas de consumo que conduzem à conclusão de contratos de impulso.

11 - A primeira ilustração desses direitos de arrependimento doravante integrados no Código do Consumidor, foi veiculada via Lei de 22 de dezembro de 1.972 sobre a venda a domicílio. Segundo as disposições do artigo L. 121 -25, o consumidor que solicita a domicilio beneficia-se de um prazo de sete dias, incluindo feriados, a contar de seu pedido, para fins de "renúncia". A partir de então, esse mecanismo protetor se dispersou pelo Código. É assim que o consumidor dispõe de um prazo de sete dias para retomar seu compromisso nas operações de crédito mobiliário ao consumo ${ }^{31}$, nas vendas ou prestações de serviço à

\footnotetext{
25 Como é matéria de crédito imobiiiário, podemos pensar que se trata, pelas mesmas razões, de uma nulidade relativa sujeita ao mesmo regime jurídico.

26 Decreto $n^{\circ} 72-1218,22$ déc. 1972 , art 23

27 C. éduc., art. L. 444-10

${ }^{28}$ Dentre vasta literatura : S. MIRABAIL, La rétractation en droit privéfranģais, LGDJ, 1997; O.LITTY,op.cit, $\mathrm{n}^{\circ} 199$ et s.; R.BAILLOD, Le droit de repentir. RTDciv. 1984, p.227 et s.; P. BRUN, Le droit de revenir sur son engagement:Dr. et patrimoine 1998, p. 78 et s.; L BERN ARDEAU, Le droit de rétractation du consommateur: JCP G 2000, p.218

29 Nesse sentido, Cass. L' civ, 10 de junho de 1992 : Bull. Civ. I n 178. A natureza jurídica desses direitos de arrependimento é contestada, alguns preferem analisá-la como um mecanismo de formação sucessiva do contrato; cf. sobre o debate, O. LITTY, op. cit., n" 230 ets.

${ }^{30}$ N.CHARDIN, Le contrat de consommation de crédit et la autonamie de la volonté, LGDJ, 1998, $\mathrm{n}^{\circ} 150$

31 Código do Consumidor, art. L. 311-15
} 
distância ${ }^{32}$, ou pela categoria particular de venda a domicílio que dispõe sobre os métodos de livre aprendizagem de línguas estrangeiras ou regionais ${ }^{33}$; esse prazo alcança dez dias no caso de contrato de usufruto de imóvel a prazo compartilhado ${ }^{34}$.

Essas preocupações consumeristas não estão todas albergadas pelo Código do Consumidor. Citamos, por exemplo, os prazos de sete dias de corretagem matrimonial ${ }^{35}$, ou do contrato sob assinatura privada de aquisição ou construção de um imóvel de habitação ${ }^{36}$, o de dez dias relativo às operações de venda a domicillio financeiro ${ }^{37}$ ou ainda o de trinta dias para contratos de seguro de vida superiores a dois meses ${ }^{38} \ldots$

Essa lista, não exaustiva, resultado de intervenções paulatinas do legislador, confere um sentimento de heterogeneidade, quiçá arbitrário. A disparidade de situações demonstrase tanto mais acentuada que as diferenças não se limitam ao quantum do prazo confiado ao consumidor, mas sim no que se refere ao modo de cálculo ou sobre a maneira de exercer a retratação. Ademais, a imprecisão do vocabulário empregado pelo legislador é bastante consternante : indiferentemente, é questão de direito a faculdade de "retomar" seu compromisso ${ }^{39}$, de" retratação" ${ }^{40}$, de "resilir" o contrato ${ }^{41}$, ou ainda, de 'renunciar" 42 . Por vezes, a lei mistura, por meio de um mesmo contrato, as expressões de prazo de reflexão e de renúncia ${ }^{43} \ldots$ E passaremos silentes às variedades de sanções penais de comportamento de profissionais de maneira a contrariar o exercício do arrependimento dos consumidores.

12 - Restaurar a coerência nesse mundo heteróclito parece eminentemente desejável ${ }^{44}$. $\mathrm{Na}$ linha da prática majoritária, poderemos sugerir a referência ao direito de se retratar num prazo de sete dias a contar do dia da aceitação da oferta do profissional ou do recebimento do bem, segundo os casos, desde que o consumidor tenha sido previamente informado da existência de seu direito ${ }^{45}$.

Normalmente, esse direito de retratação não se cumula com uma reflexão prévia à conclusão do contrato, pois não há como satisfazer duas vezes a mesma necessidade de tempo do consumidor. ${ }^{46}$

\footnotetext{
${ }^{32}$ Código do Consumidor., art. L. 121-20; esse prazo alcança quatorze dias no caso de serviços financeiros à distância: art. L. 121 20-12.

${ }^{33}$ Código do Consumidor., art L.1221-33, al.3. Nesse caso, o prazo de sete dias é prolongado para quinze dias "após o recebimento do produto pelo cliente para fazer a remessa do produto com o fim de reembolso".

${ }^{34}$ Código do Consumidor, art. L. 121-64, al.2.

35 Lei $1^{\circ} 89-421$ de 23 de junho de 1989 , art. 6, II.

$36 \mathrm{CCH}$, art. L. 271-1

37 Código Monetário, art. L. 341-16

38 Código de Seguro, art. L. 132-5-1

39 Código do Consumidor, art. L. 311-15; lei de 23 de junho de 1989, art. 6.

40 Código do Consumidor, art. L. 121-20, L.121-64, L. 311-15; C.monét., art. L. 341-16; CCH, art. L. 271-1.

41 Código da Educação, art. L. 444-8.

42 Código do Consumidor, art. L. 121-25; C. assur., art. L. 132-5-1

43 Cf. Código do Consumidor, art. L. 121-26 e L 121-5 para venda a domicílio.

44 V. também L. BERNARDEAU, chron. Préc.

45 CJCE, 13 de decembro de 2001, aff. C-481/99, Heininger: Rec I,9965.

46 Todavia, considerar o caso de ensino à distância: Código da Educação, art. L. 444-8, al. 1" e 3.
} 
Por outro lado, na linha de entendimento da Corte de Justiça das Comunidades Européias (CEJE), para a interpretação do decreto de 20 de dezembro de 1985, relativo à proteção dos consumidores em contratos negociados fora de estabelecimentos convencionais $^{47}$, convém insistir sobre dois aspectos importantes desses direitos de retratação, a saber seu caráter arbitrário e gratuito. $\dot{E}$ assim que o consumidor pode exercer seu direito sem ter que demonstrar que ele foi "influenciado ou manipulado" pelo comerciante, e que é ilícita a cláusula do contrato cujo teor abriga o pagamento de uma indenização compulsória, para o fim de compensar os danos que a retratação pode vir a causar ao profissional. Esse princípio de gratuidade não é contrariado pela obrigação atribuída ao consumidor, segundo os casos, de suportar determinadas consequências advindas de sua retratação, como as taxas de reexpedição de coisa recebida em razão de seu próprio pedido ${ }^{48}$ ou, o custo de serviços já fornecidos 49 ou, mais geralmente, o de "retorno dos bens sem seu estado inicial" 50 após a execução, pelo profissional, de sua prestação.

\section{2) Para completar seu vínculo}

13 - Na linha do direito comum contratual, o devedor deve executar sua obrigação no prazo convencionado de comum acordo com o credor. $\mathrm{O}$ Código Civil fornece muitas ilustrações: segundo as disposições do artigo 1728, o comprador "deve pagar o preço do arrendamento nos termos convencionados", da mesma forma que o artigo 1650 dispõe que " a obrigação principal do comprador é de pagar o preço no dia e lugar convencionados pela venda "e que o artigo 1657 evoca o " termo convencionado" pela retirada da coisa adquirida ${ }^{51}$.

Ora, quando o devedor enfrenta dificuldades para respeitar o prazo de execução de sua obrigação, mesmo o direito comum, por meio dos artigos 1244-1 3 e seguintes do Código Civil, faculta-lhe endereçar o pleito ao juiz para requerer um prazo de suspensão, limitado a dois anos ${ }^{52}$. A partir da reforma do direito processual civil de execução, pela lei de 9 de julho de 1991, o juiz pode também decidir que, durante esse prazo, a taxa de juros de trocas realizadas será reduzida, assim como os pagamentos recairão prioritariamente sobre o capital.

Por outro lado, todas as penalidades incorridas pelo devedor em razão de seu atraso não serão devidas durante o prazo de suspensão judicial..$^{53}$

No que respeita a todas as relações contratuais, essas disposições são, portanto, suscetiveis de aplicação em proveito do consumidor em dificuldade, a despeito de regras específicas mais favoráveis.

47 CJCE, 22 de abril de 1999, aff. C. 423/97, Travel Vac. Rec. I, 2216; L. BERNARDEAU, chron. préc.

48 Código do Consumidor, art. L. 121-20.

49 Cf. Código da Educação, art. L. 444-8,al 3 et 4 .

50 CJCE, 25 de outubro de 2005, aff. C-350/03, Schulte, cons. 92 www.curia.eu.lnt/

51 Contudo, compete ao vendedor provar que ele disponibilizou o produto vendido ao comprador no prazo convencionado: Cass. 1 er civ., 19 de março de 1996 : Bull. Civ. L]I , ${ }^{\circ} 147$.

52 G. PAISANT, La réforme du délai de grâce par la loi du 9 juillet 1991 [ . . ]: Contrats, conc consom. Déc $1991 ;$ A SÉRIAUX, Réflexiones sur les délais de grâce: RTD civ. 1993, p. 789 et $\mathrm{s}$.

53 C. civ.art $1244-2$. 
14 - A este respeito, de importância inigualável, podemos citar dois mecanismos específicos no Código do Consumidor.

15 - Em primeiro lugar, de acordo com as disposições do artigo L. 313-12, por referência aos artigos 1244-1 a 1244-3 do Código Civil e às mesmas condições, as obrigações do consumidor podem ser suspensas pelo juiz, no mesmo limite de dois anos e com as mesmas medidas de acompanhamento, no caso de dificuldades de reembolso de um crédito móvel ou imóvel ao consumo, notadamente no caso de dispensa do devedor.

Contudo, na proteção do consumidor, a lei vai mais longe. Enquanto que, pelo Código Civil o juiz não pode reduzir a taxa de juros aquém da taxa legal, o mesmo artigo $\mathrm{L}$. 313-12 autoriza, neste caso, a supressão pura e simples destes juros. A decisão aqui não terá a necessidade de ser "especial e fundamentadd" 54 .

Por outro lado, para evitar que, pela expiração do tempo de suspensão atribuído pelo juiz, o tomador possa exigir o pagamento imediato das trocas efetuadas, o mesmo texto prevê que a decisão poderá determinar as modalidades de pagamento das somas tornadas exigiveis sem permitir, contudo, "que o último pagamento possa exceder em mais de dois anos o termo inicialmente previsto para o reembolso do empréstimo"; o que autoriza a prolongar o contrato de acordo com o interesse do consumidor.

Por fim, contrariamente à jurisprudência que tem por base o Código Civil ${ }^{55}$, a Corte de Cassação decide que, em virtude do artigo L. 313-12, o juiz pode, não obstante a decadência do termo adquirido em proveito do credor, suspender as obrigações do devedor ${ }^{56}$. Ou seja, que neste caso o perdão judicial poderá macular as disposições do contrato sobre a sua própria existência; ele terá por fim a suspensão dos efeitos da decadência.

16. - Mas é sobretudo por ocasião de um procedimento de superendividamento que os ventos sopram a favor dos devedores enquanto consumidores, dado que apenas as suas dívidas não profissionais são levadas em conta para o acesso ao beneficio do referido procedimento ${ }^{57}$.

Desde a primeira lei, de 31 de dezembro de 1989, uma das medidas essenciais suscetíveis de retificar a situação do interessado reside no reescalonamento ou no adiamento das suas dívidas. Limitado originalmente a uma duração de cinco anos, este tem sido sucessivamente aumentado para oito anos, e seguidamente para dez anos, pelas reformas de 29 de Julho de 1998 e $1^{\circ}$ de Agosto de 2003, na hipótese do superendividamento genérico referido na primeira alínea do artigo L. 330-1. Desde a última reforma, mesmo as dívidas fiscais podem ser objeto desta medida de suspensã $0^{58}$, três categorias de dívidas são, todavia, tendentes ao desvio ${ }^{5 \%}$ : as reparações pecuniárias atribuídas às vítimas de uma infração penal, as multas penais e, desde o prenúncio, as dívidas alimentícias. Nesses três casos, com efeito, a situação do devedor não é considerada como prioritária.

\footnotetext{
54 Código Civil, art. 1244-1, al. 2

55 Câmara Comercial da Corte de Cassação, 19 de dezembro de 1991: Contrats, conc, consom. 1992, $1^{\circ}$ 23, obs. LEVENEUR; vide, em complmentação, Câmara Cível da Corte de Cassação, 2 de julho de 1860: DP 1860, 1, 284

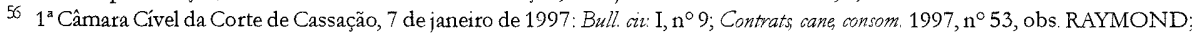
28 de setembro de 2004 , recurso (pounor) $\mathrm{n}^{\circ} 02-15757$, inédito

57 Código do Consumidor, art. L. $330-1$, al. $1^{\circ}$

58 Código do Consumidor, art. L. 331-7

59 Código do Consumidor, art. L. 333-1-
} 
A lei de $1^{\circ}$ de Agosto de 2003 estabeleceu o limite de dez anos mesmo no caso de uma correção amigável ${ }^{60}$, o que, neste caso, representa uma restrição - de resto bastante realis ta - à liberdade contratual tão favorável ao credor quanto ao devedor.

Por outro lado, no caso específico dos empréstimos em curso, o artigo L. 331-7 oferece uma opção dentro do interesse do devedor: o prazo de reescalonamento não pode exceder dez anos ou "a metade da duração de reembolso restante a transcorrer ". Esta última solução pode revelar-se mais vantajosa ao credor, no caso, por exemplo, de um empréstimo imobiliário inicialmente concluído por um longo período: trinta ou mesmo trinta e cinco anos, como mostram as práticas atuais. E, no caso da decadência operar-se em desfavor do credor, este prazo não poderá atingir a metade da duração que permanecia a correr antes da decadência. Esta precisão, sempre no interesse da pessoa endividada, foi acrescida ao artigo L. 331-7 pela lei de 8 de Fevereiro de 1995, em reação à jurisprudência da Corte de Cassação, a qual considerava que, devido à decadência, o empréstimo não estava mais "em curso" e que, conseqüentemente, apenas o prazo de cinco anos (à época) deveria ser considerado ${ }^{61}$.

Permanece, contudo, um limite em favor manifesto do consumidor nessas circunstâncias: A Corte de Cassação récusa a cumulação entre os prazos de reescalonamento do artigo L. 331-7 do Código do Consumidor e o prazo de perdão judicial de dois anos do Código Civil ${ }^{62}$. Com efeito, teria sido incoerente acrescentar aos prazos especialmente atribuídos aos devedores em grande dificuldade os concebidos à vista de situações menos preocupantes. As disposições especiais prevalecem aqui logicamente sobre as disposições de caráter geral.

Seguindo a mesma linha de entendimento, não é conveniente acumular a duração de dez anos com a que permanece a correr no caso de um empréstimo em curso. Não somente, com efeito, a lei verbaliza a forma de alternativa na matéria, mas ainda, esta segunda possibilidade refere-se a uma medida especial própria a uma categoria de dívidas.

Não se pode, contudo, excluir um desvio, em proveito do devedor, das disposições legais sobre o prazo máximo de reescalonamento. A Corte de Cassação admite, com efeito, que, por seqüência de um fato novo que o coloca na impossibilidade de honrar os prazos reescalonados, o devedor tem a faculdade de beneficiar-se de um novo procedimento, se as condições de abertura forem novamente reunidas ${ }^{63}$. De plano em plano, a regra dos dez anos poderia assim ser destruída...

17 - No caso mais grave de superendividamento, que é o da "insolvência" ", a lei também faz uso do tempo em prol do devedor; contudo, desta vez, de uma maneira totalmente diferente. Enquanto que, no caso anterior, o tempo atribuído ao devedor figurava

(1) Código do Consumidor, art L. 331-6.

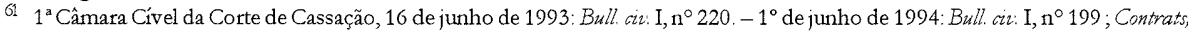
conc, consom 1994, $\mathrm{n}^{\circ} 187$, obs. RAYMOND.

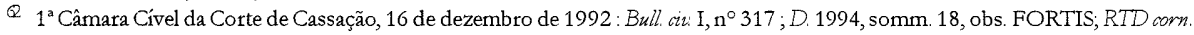
1993, p. 174

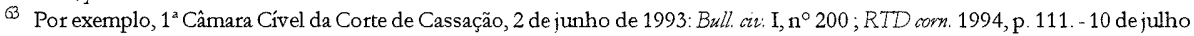
de 1995: Bull. civ: $\mathrm{I}, \mathrm{n}^{\circ} 318$; RTD com 1995, p. 843.

64 Código do Consumidor, art. L. 331-7-1: "Ausência de recursos ou de bens penhoráveis de modo a permitir apurar a totalidade ou parte" das dívidas "e tomadas inaplicáveis as medidas previstas no artigo L. 331-7", sem contudo que esta situação apresente "um caráter irremediável". 
como um meio para resolver as suas dificuldades, no caso da insolvência os prazos concedidos constituem apenas um prelúdio, de natureza conservatória, a remédios mais importantes. Está apenas na espera, de acordo com a evolução da situação do devedor, quer das medidas de correção do artigo L. 331-7 (entre os quais o reescalonamento durante dez anos), quer da extinção parcial das suas dívidas ou a combinação dos dois ${ }^{65}$, a atribuição ao interessado de uma única suspensão de exigibilidade das dívidas outras que as alimentares, durante uma duração máxima de dois anos ${ }^{66}$, sera accordée à l'interessé.

No mesmo sentido, a hipótese de uma "situação irremediavelmente comprometida" e a abertura de um restabelecimento pessoal, a suspensão dos procedimentos de execução diligenciados contra o devedor durante toda a duração do procedimento ${ }^{67}$ constitui normalmente apenas o prelúdio à medida radical de extinção das dívidas não profissionais inerente ao julgamento de encerramento para insuficiência de ativo.

Mas, enquanto que o devedor que vale-se da extinção parcial das suas dívidas ao abrigo da sua "insolvência" deve esperar oito anos antes de obter uma medida da mesma ordem para dívidas similares ${ }^{68}$, nenhuma restrição deste tipo tem sido lograda no âmbito de um procedimento de restabelecimento pessoal ${ }^{69}$. Esta diferença, sobretudo neste sentido, não é razoável.

18 - Atribuindo assim tempo ao consumidor para preencher o seu compromisso (ou antes de atenuar o encargo), o legislador abre assim o caminho, sob o controle do juiz, a arranjos contratuais. São outros arranjos que convém considerar para apreciar o controle do tempo conferido em diversas circunstâncias ao consumidor.

\section{B - O tempo controlado pelo consumidor}

19 - De acordo com os princípios do Código civil, a duração da relação contratual é determinada livremente pelas partes, sob reserva dos compromissos perpétuos ${ }^{70}$. Mas, para que a escolha desta duração seja realmente livre, ainda é necessário que uma das partes não esteja em estado de impor seus objetivos ao outro ${ }^{71}$. É por isso que não será surpresa constatar que, sobre este ponto ainda, o legislador interveio de maneira específica em prol do consumidor, para evitar que a duração do contrato seja definida unicamente em função dos interesses do profissional.

Em especial, convém evitar que o consumidor se ençontre preso a um contrato que, em razão da evolução das circunstâncias, tenha se tornado contrário aos seus interesses legítimos e seja voltado a impedi-lo de valer-se da concorrência em seu favor. Várias técnicas têm sido aplicadas para esse efeito.

\footnotetext{
65 Arg. avis C. cass., 10 de janeiro de 2005 : RTD com. 2005, p. 424 e s.; vide, em complementação, TI Vienne, 25 de novembro de 2002: RTD corn 2003, p. 174. - $2^{2}$ Câmara Civel da Corte de Cassação, 22 de março de 2006, recurso (pounnot) n 04-04140, inédito.

${ }^{6}$ Código do Consumidor, art L. 331-7-1

a Código do Consumidor L. $332-6$

\& Código do Consumidor, art. L $331-7$ - 1, al. 2

(7) Avis HYEST, DOC. Sénat n $n^{\circ} 404$, sessão extraordinária 2002 - 2003 , p. 25

70 Supra, al 2

71 O. LITTY, op, cit, 54 e s.
} 
20 - Em primeiro lugar, de maneira excepcional, no caso do crédito renovável, o Código do Consumidor, no seu artigo L. 311-9, limitou expressamente a duração do contrato inicial. Este limite é fixado em um ano. Mas é, realmente, pouco vinculativo para o órgão credor, dado que a lei fala em "um ano renovável". Em um outro caso específico, o dos contratos de prestações de serviços de comunicações eletrônicas, o artigo L. 121-84, originário da lei de 9 de Julho de 2004, prevê que o consumidor poderá cancelar o contrato, sem penalidade, caso recuse a modificar as condições contratuais propostas pelo profissional.

21 - Precisamente, para casos além destes específicos, uma lei de 28 de Janeiro de 2005, que introduziu o artigo L. 136-1 no Código do Consumidor, estabeleceu um dispositivo próprio para permitir ao consumidor, apesar da presença de cláusula tácita de renovação no contrato, conservar certo controle da duração da relação contratual. Na matéria, veremos de resto que a lei começa por impor uma obrigação de informação ao profissional, de sorte que o consumidor tenha a capacidade de, quando chegar o momento, pôr um termo ao contrato que não corresponderia mais às suas necessidades ou ao seu interesse $\mathrm{e}^{72}$.

22 - Sobretudo, no caso do crédito ao consumo, a lei oferece em várias ocasiões ao consumidor a faculdade de pôr fim ao contrato unilateralmente antes do previsto, e mesmo quando esta ruptura antecipada não se explique por si só, nem por qualquer descumprimento do profissional às suas obrigações, nem pela ocorrência de uma causa externa. Por simples conveniências pessoais, o consumidor terá por conseguinte o direito de sair de maneira antecipada do contrato. Isto visa a duas hipóteses: a rescisão do crédito renovável e o reembolso antes de termo do crédito ao consumo.

\section{1) A rescisão antecipada do crédito renovável}

23 - Acrescentada à al.3 do artigo L. 311-9 do Código do Consumidor, a lei de 28 de Janeiro de 2005 dispõe doravante que "a qualquer momento" o credor poderá pedir não somente a redução da sua reserva de crédito ou a suspensão do seu direito a utilizá-la, mas ainda "a rescisão do seu contrato".

Por conseguinte, neste tipo de operação de crédito, o consumidor não sofre nenhum constrangimento temporal. Transcorrido o prazo de sete dias para arrepender-se, pode ainda, quando o desejar, e mesmo antes da expiração da duração inicial de um ano, pôr fim ao contrato de maneira arbitrária. A lei não exige nenhuma justificativa da sua parte.

A intenção do legislador é clara. Trata-se, por esta disposição, de trazer uma pedra suplementar ao edifício de prevenção das situações de superendividamento ${ }^{73}$. $O$ crédito renovável, pelas facilidades que oferece, é considerado, com efeito, um mecanismo perigoso a esse respeito. Se, por razões econômicas, não se pode proibi-lo, a posição adotada foi no sentido de "melhor enquadrá-lo"74. Esta disposição foi apresentada como "um progresso considerável" ${ }^{375}$ na matéria.

72 Infra, $\mathrm{n}^{\circ} 35$ es.

73 Relator CHATEL, DOC. ANn ${ }^{\circ} 1271,12^{\circ}$ lég, p. 17 es.

74 Assim se intitulou o Título II da lei de 28 de janeiro de 2005.

T5 Declaração de CORNU JO Sénat CR, 22 de junho de 2004, p. 4528 
Realmente, este progresso é sem dúvida menos "considerável" ${ }^{376}$ que a derrogação que se encontra plasmada nos princípios contratuais, dado que, finalmente, o consumidor não será vinculado pela duração inicial de um ano da abertura de crédito.

Se este último não quer correr o risco de endividar-se, não lhe continua permitido evitar extrair a reserva de crédito que the é oferecida, sem, no entanto, ir até à rescisão do contrato? Trata-se, por conseguinte, de proteger o consumidor contra ele mesmo e suas próprias tentações contra a prática contratual do órgão de crédito.

24 - O Código do Consumidor não especifica as modalidades práticas desta rescisão antecipada. O legislador não chegou a prever, como para o exercício do direito à retratação, a existência de um registro de rescisão. Nenhuma forma específica é necessária. Mas, por evidentes razões probatórias, o uso da carta com aviso de recepção seráa útil ${ }^{77}$.

A esse respeito, a lei de 28 de Janeiro de 2005 dispẽe que esta rescisão obriga o credor "a reembolsar, nas condições do contrato, o montante da reserva de dinheiro já utilizada". Esta referência às condições do contrato retorna às disposições do parágrafo 2 do artigo $\mathrm{L}$. $311-9^{78}$, que refere o reembolso "que deve ser escalonado, salvo vontade em contrário do devedor". Este último encontra-se, por conseguinte, na situação que seria a sua se, recém chegado no fim do período inicial, indicasse a sua intenção de não renovar o contrato.

Esta faculdade de rescisão antecipada efetua-se, assim, sem nenhuma penalidade contra o consumidor. Não é necessário dissuadi-lo de procurar à desoneração das dívidas.

\section{2) $\mathrm{O}$ reembolso antecipado do empréstimo}

25 - De acordo com o direito comum, o empréstimo de dinheiro deve ser reembolsado de acordo com os prazos acordados, de modo que nem o credor, tampouco o tomador, possam impor um reembolso antecipado. Sem dúvida, o artigo 1187 do Código Civil prevê que "o termo sempre é estipulado em prol do devedor", o que seria para permitir ao tomador liberar-se por antecipação se ele encontra vantagem. Mas o mesmo texto acrescenta uma restrição a este princípio: "a menos que resulte da estipulação ou das circunstâncias que ele também foi acordado pelo interesse do tomador". E esta situação corresponde bem ao empréstimo de dinheiro, no qual os reembolsos escalonados são estabelecidos pelo interesse comum $^{79}$ : o banqueiro tem, com efeito, tanto interesse em escalonar as suas reentradas de dinheiro quanto o tomador em efetuar os seus pagamentos em função do calendário de percepção dos seus rendimentos ${ }^{80}$. Naturalmente, o contrato pode autorizar um reembolso antecipado, mas, neste caso, imporá ao tomador que verta uma compensação financeira ao órgão credor, à razão, ao mesmo tempo, das despesas de gestão ligadas a esta mudança e da perda de uma parte dos interesses esperados.

\footnotetext{
76 Vide, comparativamente, H. ClARET, La loi $n^{\circ} 2005-67$ du 28 janzier 2005 tendant à conforter la confiance et la protection du consommateur: JCP G $2005,1,140, \mathrm{n}^{\circ} 27$, que considera esta disposição como "supérflua", tendo em vista o fato de "que o contrato tem a duração de um ano".

7 Cf. no mesmo sentido, H. CLARET, art. cit, $\mathrm{n}^{\circ} 28$.

78 A redação inicial da proposição da lei, de resto, neste sentido: Doc. $A N_{n}{ }^{\circ} 1141,12 \mathrm{e}$ lég., p. 4 . A atual redação foi considerada mais precisa pelo Senado: JO Sénat $C R, 22$ de junho de 2004, p. 4527.

72 Req. 21 de abril de 1896: DP 1896, 1, 484, Relator VOISIN.

8 F. COLLART-DUTILLEUL e P. DELEBECQUE, Contrats cinils etcommerciaux, $7^{2}$ ed., Dalloz, 2004, $n^{\circ} 285$
} 
26 - O Código do Consumidor é mais favorável ao tomador ${ }^{81}$. Para permitir a este último exonera-se das dívidas mais cedo, por exemplo, na seqüência de uma reentrada de dinheiro imprevista, ou ainda, em período de baixa das taxas de juro, de modo que possa liberar-se contraindo outro empréstimo a uma taxa muito mais vantajosa, o legislador atribui-lhe o direito de reembolsar por antecipação. Trata-se dos artigos L. 311-29 e L. 312-21 para, respectivamente, os créditos móveis e os imobiliários ao consumo.

27 - No caso do crédito móvel, o direito reconhecido ao consumidor é tão mais forte que, não somente pode ser exercido de maneira arbitrária e em qualquer momento à sua iniciativa, mas que também desde uma lei de 31 de Dezembro de 1989, efetua-se sem que o órgão credor possa reclamar por outro lado a mais mínima indenização.

Uma única restrição figura no artigo L. 311-29: o credor poderá recusar um reembolso parcial antecipado que seja inferior à três vezes o montante contratual do primeiro prazo não cabido $^{82}$. As complicações que este reembolso antes do termo geram em detrimento do organismo bancário não devem, com efeito, se mostrar demasiado importantes em relação às vantagens esperadas pelo consumidor. Mas este limite não deve ocultar o princípio: a lei permite o reembolso antecipado, tanto total como parcial.

28 - Tal prerrogativa é igualmente reconhecida ao consumidor no domínio do crédito imobiliário. Como no caso precedente, e pelas mesmas razões, o tomador pode exercer esta faculdade quando lhe parece bom e de maneira arbitrária, não obstante qualquer cláusula contrária.

A partir desta base comum, o artigo L. 312-21 põe duas séries de regras específicas aos reembolsos de empréstimos imobiliários.

29 - A primeira refere-se às restrições aos reembolsos que seriam apenas parciais. Sobre a matéria, a lei prevê que o contrato pode proibi-los quando forem "iguais ou inferiores a dez por cento do montante inicial do empréstimo". Como no caso de um crédito móvel, trata-se de evitar ao profissional despesas desproporcionais em relação à economia esperada do consumidor. Mas o regime desta restrição é aqui diferente. Não somente o limiar mínimo de reembolso fixado pela lei não é o mesmo, mas ainda, contrariamente às disposições do artigo L. 311-29, está previsto que este limite não é levado a efeito quando o reembolso em questão é destinado a pagar o saldo do empréstimo.

30 - A segunda especificidade é mais notável: o artigo,L. 312-21 autoriza o credor a reclamar do tomador o pagamento de uma indenização de reembolso antecipado em decorrência de interesses não-ocorridos (intérêts non échus). A diferença de regime em relação ao crédito mobiliário explica-se, sem dúvida, neste caso, pela diferença dos interesses envolvidos. Os empréstimos imobiliários são, geralmente, de longa duração e envolvem um maior número de interesses, o que implica que, nesse caso, haverá maior importância em respeitar o plano de reembolsos previamente estabelecido. É evidente, no entanto, que o credor apenas poderá demandar essa indenização se ela for expressamente prevista no contrato. O artigo L. 312-23 estabelece que nenhuma outra soma de dinheiro poderá ser exigida do consumidor.

8: Cf. J.R. MIRBEAU-GAUVIN, Le remboursement anticipé du prêt en droitfranģais. D. 1995, chron. 46 e s. ; O. LITTY, op. cit, $1^{\circ} \mathrm{s} 364$ es

82 Código do Consumidor, art. D. 311-10 
Nessa matéria, a liberdade contratual é particularmente limitada. A indenização suscetível de ser reclamada do consumidor é sujeita a um limite máximo para evitar que seja demasiado dissuasiva. Ela "não pode exceder o valor de um semestre de juros sobre o capital reembolsado à taxa média do empréstimo, sem poder exceder $3 \%$ do capital ainda devido antes do reembolso" ${ }^{\prime 83}$. Em casos específicos, como o dos empréstimos a taxas progressivas, onde são acompanhados de taxas diferenciadas de acordo com os períodos, a indenização devida poderá ser objeto de uma majoração em relação à hipótese precedente. Essa majoração corresponderá à "soma que permitir assegurar ao credor a taxa média prevista na concessão do empréstimo relativa ao tempo decorrido desde a o início" "84.

Nos dois casos, de acordo com as disposições do artigo L. 312-21, a demanda de pagamento, realizada pelo credor, da verba indenizatória de reembolso antecipado devidamente limitada efetua-se "sem prejuízo da aplicação do artigo 1152 do Código civil". Logo, mesmo que a indenização reclamada permanecesse nos limites do teto legal, o tomador teria, por conseguinte, a faculdade de solicitar a sua moderação pelo juiz, em razão de, na circunstância dada, ela parecer "manifestamente excessiva".

Até o momento, no entanto, pelo menos no caso específico dos empréstimos a taxa progressiva, a Corte de Cassação frustrou esse mecanismo, pelo duplo motivo de que o poder discricionário que o juiz extrai do artigo 1152 do Código civil apenas conceme às cláusulas penais ${ }^{85}$, que, precisamente, não são as cláusulas de reembolso antecipado, que têm por objeto "restabelecer uma taxa média constante", e não "assegurar a execução das obrigações do tomador" ". A causa da obrigação de pagar essa indenização consiste na reparação dos lucros cessantes (mamque à gagner) sofridos pelo credor em decorrência da resilição (résiliation) antecipada do contrato. ${ }^{87}$

O resultado desse raciocínio é criticável: a remissão (renvor) ao Código civil, por meio do artigo L. 312-21, não significa, necessariamente, que a cláusula de reembolso antecipado constitui uma cláusula penal. O reembolso tem simplesmente por objeto atribuir, no interesse do consumidor-tomador, à primeira um elemento do regime jurídico da segunda. Sem dúvida, teria sido mais oportuno se a lei tivesse se referido, nessas circunstâncias, ao poder discricionário do juiz sem menção ao artigo 1152 do Código civil.

Tanto é assim que, sempre que há um empréstimo a taxas progressivas, a Corte de Cassação (Cour de Cassation) exige, sob pena de dacadência do direito, que as modalidades de cálculo desses juros compensatórios sejam "indicadas na oferta preliminar (offre préalable), de modo a permitir ao tomador ter conhecimento do máximo que poderia dever no caso de reembolso antecipado" ${ }^{\prime 88}$.

83 Código do Consumidor, art. R. 312-2, al. $1^{\mathrm{a}}$.

84 Código do Consumidor, art. R. 312 2, al 2; cf. M. LE SON, L'indemnité de remboursement anticipé d'un prêt immobilier de consommation: RD bancaine et bourse, 1991, p. 213.

85 Acerca dessa jurisprudência, cf. G. PAISANT, Rép. ciz: Dalloz vide cláusula penal, 2003, n. ${ }^{\circ} 69$ es

86 Cass $1^{\text {re }}$ civ., 7 de outubro de 1992: Bull. civ: $1, \mathrm{n} .^{\circ} 245 .-2$ de dezembro de 1992: Bull ciz: 1 , n. 301 ; Contrats, conc, consom, 1993 , $\mathrm{n} .^{\circ} 41$, comentários de LEVENEUR - 30 de matço de $1994:$ Bull civ:, $\mathrm{n} .^{\circ} 129 .-11$ de outubro de $1994:$ Bull civ $I, \mathrm{n} .^{\circ} 289$. - Vide, contudo Cass. $1^{\text {re }}$ civ., 20 de março de 1989: Bull, ciz: $1, \mathrm{n}{ }^{\circ} 138$.

87 Cass. $1^{\text {re }}$ civ., 27 de setembro de 2005: D. 2005; 2670, comentários de X. DELPECH; Defrénois, 2005, p. 2003, coment. de SAVAUX, 2006, p. 332, nota PIEDELIÈVRE.

88 Cass. $1^{\text {te }}$ civ, 30 de março de 1994, cit -21 de fevereiro de 1995 : Bull cin $1, \mathrm{n} .^{\circ} 99$; vide, como complementação, 8 de julho de 1994, Contrats, conc consom., 1994, n. ${ }^{\circ} 241$, comentários de RAYMOND. 
Para escapar também ao pagamento dessa indenização, alguns tomadores invocaram a nulidade da cláusula com fundamento no artigo 1129 do Código civil, relativo à indeterminação do objeto. Mas se essa orientação, durante certo tempo, encontrou eco na Corte de Cassação (Cour de Cassation) relativamente a empréstimos não submetidos ao Código do Consumidor, com base no fato de que a indenização não estaria determinada em consonância com elementos exteriores à vontade das partes ${ }^{89}$, hoje ela foi abandonada; esses elementos estão incluídos nas relações consumeristas ${ }^{90}$.

Desde uma lei de 25 de junho de 1989, relativa a empréstimos imobiliários subscritos a partir de 30 de junho do mesmo ano, apenas são exonerados do pagamento de qualquer indenização os tomadores cujo reembolso antecipado é motivado pela venda do bem imobiliário financiado pelo empréstimo como conseqüência de uma mudança superveniente no local de exercício de sua atividade profissional ou da do seu cônjuge. Contudo, essa dispensa só vale se a referida mudança resulta do falecimento do tomador ou de seu cônjuge, ou ainda da cessação forçada da atividade até então por ele exercida ${ }^{91}$. Para facilitar a mobilidade profissional, por exemplo, para sair de uma situação de desemprego, poder-se-ia ter sido menos restritivo.

Apesar do princípio subsistente ${ }^{92}$ da licitude da indenização do reembolso antecipado no domínio imobiliário, essa faculdade que se reconhece ao consumidor de sair do contrato antes do termo acordado parece um verdadeiro "privilégio" ${ }^{93}$. Ela constitui um dos meios previstos pelo legislador para compensar a desigualdade contratual entre profissionais e consumidores. Há, no entanto, outros meios, porque se o tempo pode jogar em favor dos últimos, ele também gera limitações específicas em relação aos primeiros.

\section{II - A pressão do tempo para o profissional}

31 - Nos contratos que o vinculam aos consumidores, o profissional não sofre a pressão do tempo apenas no dever de respeitar os direitos conferidos aos primeiros. A coação nada mais é do que o inverso do favorecimento do tempo consentido aos consumidores.

Essa coação igualmente se externaliza, de maneira direta, por meio das obrigações positivas impostas aos profissionais em benefício do consumidor (A), ou, ainda, indiretamente, através dos limites que a legislação destina às cláusulas abusivas na determinação do conteúdo do contrato (B).

89 Cass. com., 15 de dezembro de 1992: Bull az: IV , n. ${ }^{\circ} 417$. - Cass. $1^{\text {te }}$ civ, 22 de junho de 1994:D. 1995, 368, nota de A. PENNEAU. - 9 de maio de 1996: Contrats, conc, consom, 1996, n. ${ }^{\circ} 136,2^{\circ}$ esp., nota de LEVENEUR.

$\because$ Cass. $1^{\text {re }}$ civ., 6 de março de 2001: Bull. ch. I, n ${ }^{\circ} 184 ;$, D. 2001, 1172, comentários de AVENA-ROBARDET; para um outro tipo de empréstimo: Cass. $1^{\text {re }}$ civ., 14 de junho de 2000: Bull. ci2: 1, n. ${ }^{\circ}$ 184; D. 2001, 1136, comentarios de D. MAZEAUD; em complementação, vide Cass. $1^{\text {re }}$ civ., 2 de março de 2004, recurso (pourzoz) n. ${ }^{\circ} 01-11920$, inédito.

9. Vide A. GOURIO, L'indemnité de remboursement anticipé des préts au logement: une demi-réforme, RD bancaire et bourse, 1999, p. 160.

92 Acerca da contestação desse princípio, vide J. HUET, Les principaux contrats spéciaux, LGDJ, 1996, n. ${ }^{\circ} 22550$; J. CALAIS-AULOY e F. STEINMETZ, Droit de la consommation, $\sigma^{a}$ edição, Dalloz, 2003, n. ${ }^{\circ} 429$, p. 476, nota 1.

93 Y. PICOD e H. DAVO, Drait de la consommation, Armand Colin, 2005, n. ${ }^{\circ} 306$. 


\section{A - As obrigações positivas impostas ao profissional}

32 - O tempo gera obrigações ao profissional, tanto na ocasião da formação ou renovação do contrato de consumo, quanto sob a perspectiva de sua execução.

\section{Na ocasião da formação ou da continuação do contrato}

33 - As obrigações aqui impostas aos profissionais integralizam os direitos reconhecidos aos consumidores na medida em que são destinadas a facilitar o seu exercício. Trata-se da obrigação do credor de manter sua oferta durante certo lapso temporal e da obrigação de informar ao consumidor em tempo hábil, para que este possa escapar a uma cláusula de continuação tácita do contrato.

34 - A obrigação, para o credor, de manter sua oferta durante um certo lapso temporal é comum aos créditos mobiliários e imobiliários ao consumo. Nos dois casos, ela é destinada a permitir ao consumidor comparar com as ofertas concorrentes e de refletir sobre suas respectivas vantagens e inconveniências. Em outras palavras, trata-se de facilitar, para o consumidor, a expressão de um consentimento claro e, então, de complementar, tanto o direito à retratação, como o direito à reflexão, este admitido pelo Código do Consumidor ${ }^{94}$. Mas o regime e o alcance dessa obrigação imposta ao credor variam de acordo com o tipo de crédito em questão.

É no caso do crédito mobiliário que ela revela uma importância menos significativa. O artigo L. 311-8 fixa em quinze dias, no mínimo, a contar de sua emissão, o prazo de manutenção da oferta de crédito. Contudo, resta claro que nada impede que o consumidor aceite essa oferta antes de expirar o prazo. Na prática, com efeito, não é raro ver o consumidor assinar a oferta preliminar no mesmo momento em que esta lhe é apresentada; o que reforça a utilidade do direito de arrependimento nessas circunstâncias. De todo modo, transcorrido o prazo de quinze dias sem que o consumidor tenha externalizado sua aceitação, a oferta emitida restaria caduca de pleno direito e o credor desonerado de levá-la adiante, a menos que um prazo mais extenso tenha sido convencionado pelas partes.

No que respeita ao crédito imobiliário, a fixação dessa obrigação é notadamente reforçada em razão da diferença dos riscos. Não somente o prazo durante o qual o credor deve manter sua oferta é fixado por um mínimo de trinta dias, a contar, dessa vez, de sua recepção pelo devedor ${ }^{95}$, mas, ainda, sabemos que o consumidor não pode validamente expressar sua aceitação antes de expirado o prazo de reflexão de dez dias que a lei lhe confere ${ }^{96}$. Considerando que os trinta dias são editados no interesse do consumidor, podemos pensar que se trata de dias francos ${ }^{97}$.

\footnotetext{
V. supra $\mathrm{n}^{\circ} 7 \mathrm{es}$.

Código do Consumidor, art. L. 312-10 al. $1^{\mathrm{a}}$.

Supra, $n^{\circ} 1$.

Do tradutor: considera-se dia franco (jour franc) um período de 24 horas a partir da hora zero. É um prazo franco, ou seja, que começa a correr após a fluência do dia inicial do prazo (dies a quo); o tempo restante antes do começo desse dia não é computado. No Brasil, é como são contados os prazos processuais, segundo o Código de Processo Civil.
} 
35 - De alcance mais geral, visto que relativa a todos os contratos de prestação de serviços, a Lei de 28 de janeiro de 2005 impôs aos profissionais a obrigação de informar a seus co-contratantes consumidores sobre a faculdade que lhes é conferida de escapar a uma cláusula de continuação tácita, por uma duração determinada ou indeterminada ${ }^{98}$, e, via de conseqüência, desfazer o contrato desfavorável aos seus interesses.

Sem dúvida, os contratos prevêem, eles mesmos, as modalidades próprias para evitar a continuação tácita, mas, em razão do duplo motivo de sua "formulação freqüentemente complexa" e do caráter "freqüentemente mal-conhecido" pelos consumidores das estipulações neles contidas", o legislador desejou obrigar o profissional a informar ao consumidor sobre a data-limite, dentro da qual ele poderá demonstrar sua intenção de desfazer o contrato ${ }^{100}$. Trata-se, com efeito, de posicionar melhor o consumidor para exercer um direito reconhecido pelo direito comum e organizado pelo contrato, garantindo-o contra a própria negligência da leitura do consumidor ou compreensão equivocada das coisas.

Mais precisamente, o novo artigo L. 136-1 do Código do Consumidor dispõe que o profissional deve informar por escrito ao consumidor, "no mais cedo, em três meses, e, no mais tardar, em um mês antes do final do prazo que autoriza a rejeição da continuação, da possibilidade de desfazer o contrato."

36. - A aplicação dessa obrigação de informação supõe, então, que o contrato tenha determinado precisamente a data-limite, antes de chegar ao final do período inicial, prazo em que o contratante consumidor pode manifestar-se eficazmente para impedir a continuação da relação. No caso contrário, devemos admitir que a informação do profissional deva ser emitida, no mais tardar, um mês antes do dia da continuação efetiva do contrato. A forma do documento mediante o qual esta informação deve ser comunicada ao consumidor não é determinada pela lei. A carta registrada com aviso de recebimento não é, então, necessária, mesmo se, na prática, suas vantagens probatórias sejam evidentes. De acordo com as circunstâncias, um documento eletrônico pode ser suficiente; em particular nos casos em que a encomenda do consumidor tenha sido efetuada desta forma. Todavia, evidentemente, é ainda necessário que haja alguma chance de o consumidor estar inserido neste procedimento. Considerando a redação da lei, podemos pensar que o profissional somente tem o ônus de provar que expediu ao endereço correto o documento informativo requisitado ${ }^{101}$. Entretanto, essa solução não é satisfatória para o consumidor, que terá de suportar um risco contra o qual não está em condições de se prevenir: o mal-encaminhamento da correspondência. Com efeito, como poderá ele provar que não recebera a informação escrita do profissional? Uma vez mais, encontramo-nos confrontados com o problema da refletividade do direito do consumidor. Mas impor ao profissional a prova da data de recepção da informação conduziria

88 É por eferto de regra, a despeito de estipulações contrárias, que a continuação de um contrato por tempo determinado o transforma em contrato por tempo indeterminado, que pode ser rescindido a qualquer momento, por meio de um pré-aviso usual (ou fixado pelo contrato) pelo interessado: cf. P. STOFFEL-MUNCK, $O$ enquadramento da continuação tácita nos contratos de consumo desde a lei Cbatel: JCP G 2005,1, $129, n^{\circ} 1$.

9 Rapp CHATEL, nota 73 acima, p. 11-12

100 H. CLARET, nota 76 acima, n 14 ; P. STOFFEL-MUNCK, art. préc

101 P. STOFFEL-MUNCK, art. préc, $n^{\circ} 7$. 
a uma inflação dificilmente controlável no sistema da carta registrada. O legislador pôs em prática os meios adequados para esta nova manifestação de proteção aos consumidores?

37 - Sendo respeitada esta obrigação de informação, caberá ao consumidor decidir-se.

Ele pode, primeiramente, escolher guardar silêncio, o que conduzirá ao seguimento da relação contratual, segundo os termos do contrato. Excepcionalmente, e segundo a regra a qual prevê que o contrato continuado é considerado como um novo contrato ${ }^{102}$, poderia parecer que, no caso dos contratos de serviços à distância, o consumidor conserva uma faculdade de retratação nos sete dias seguintes à continuação ${ }^{103}$.

Mas nos prazos estipulados no contrato, o consumidor poderia igualmente expressar sua vontade de não prosseguir com a relação contratual, após o termo inicial. Ora, embora o artigo L. 136-1 tenha concebido favorecer essa eventualidade, ele curiosamente se omite em precisar seus termos. A rigor, essa faculdade de denunciação nos parece arbitrária e gratuita. Considerando as finalidades da lei e seu caráter necessário de ordem pública ${ }^{104}$, qualquer estipulação que subordinasse a não-recondução do contrato ao pagamento de qualquer contrapartida pecuniária seria, do nosso ponto de vista, ilícita. No que respeita à forma, diante do silêncio da lei, devemos considerar que esta é livre. Mas como, pelas evidentes razões probatórias, não aconselhar os consumidores, desejosos de retomar sua liberdade com toda segurança, a recorrer a essa famosa carta registrada com aviso de recebimento ${ }^{105}$ ?

38 - Na hipótese em que, ao contrário, o profissional não respeitasse sua obrigação de informação, o artigo L. 136-1 prevê que "o consumidor pode, gratuitamente, pôr termo ao contrato, a qualquer momento, a contar da data de continuação. Para colocar em prática essa prerrogativa, o texto não distingue se o contrato prevê uma continuação por tempo determinado ou indeterminado. A solução deve então ser a mesma em ambos os casos. A expressão "a qualquer momento" significa notadamente que não será esperado do consumidor respeitar um pré-aviso qualquer, mesmo contratualmente fixado, para pôr termo ao contrato continuado ${ }^{106}$. Novamente, trata-se de um direito discricionário do consumidor.

Nessas circunstâncias, o contrato terá fim sem retroagir ao dia da continuação. Se, então, um adiantamento foi feito pelo consumidor, e se os serviços correspondentes a esse adiantamento não tenham sido integralmente providos no momento da resilição do contrato, o profissional deverá efetuar um reembolso proporcional no prazo de trinta dias ${ }^{107}$. Após esse prazo, as somas devidas produzirão juros à taxa legal; o que não representa uma forte dissuasão! A verdadeira sanção reside no direito conferido ao consumidor de retomar sua liberdade quando ele a desejar, uma vez entabulado o processo de continuação.

\footnotetext{
102 V. B. AMAR-LAYANI, A continuação tácita: D. 1996, chron. 145 et s., spéc. p. 147. Por ex. : Cass. com. 10 juin 1998 : Bull. civ. IV, $\mathrm{n}^{\circ} 119$

103 Código de Consumo, art. L. 121-20; V. P. STOFFEL-MUNCK, art. préc, n 10 et s

104 Mesmo que a lei de 28 de janeiro de 2005 não o diga expressamente.

105 Nesse sentido, H. CLARET, art. préc, $\mathrm{n}^{\circ} 18$.

106 No mesmo sentido, $H$. CLARET, art. préc, $n^{\circ} 16$

107 Código do Consumidor, att. L. 136-1, al 2.
} 


\section{Quando da execução do contrato}

39 - As pressões do tempo, as quais pesam sobre o profissional, contrastam com os favores ofertados aos consumidores quando estes devem pagar o preço dos produtos ou dos serviços que lhes são fornecidos ${ }^{108}$. Mesmo se essa diferença de situação não apresente um caráter de generalidade, duas ilustrações merecem atenção: de uma parte, a obrigação de pontualidade direcionada para a responsabilidade do profissional e, de outra, as pressões de tempo que a lei lhe impõe, a partir de agora, de maneira exclusiva, quando, em matéria de crédito ao consumo, o credor decide agir contra o devedor em mora.

40 - A obrigação de pontualidade que pesa sobre o profissional é enunciada no artigo L. 114-1 do Código do Consumidor. Esse texto se aplica às vendas de bens móveis e aos contratos de fornecimento de serviços, desde que a entrega do bem e o fornecimento da prestação não seja imediata e o preço convencionado seja superior a uma quantia atualmente fixada em 500 euros. Nesse caso, o profissional é obrigado a indicar a data-limite na qual ele executará sua obrigação, sendo especificado que, em caso de atraso superior a sete dias não causado por força maior, o consumidor estará no direito de "denunciar" o contrato por carta registrada com aviso de recebimento. Esse direito deve ser exercido dentro de "sessenta dias úteis", a contar da data indicada para a entrega do bem ou para a execução da prestação.

O profissional deve, assim, comprometer-se com um prazo suficientemente preciso de execução ${ }^{109}$ e respeitá-lo, sob reserva da força maior, apreciada geralmente de maneira restritiva pelos juízes ${ }^{110}$.

Enquanto que no prazo previsto pela lei o consumidor insatisfeito denuncia o contrato, esse último é considerado como resilido no dia da recepção, pelo profissional, da carta de denúncia. Entretanto, se "entre o envio e a recepção dessa carta" ${ }^{111}$ o profissional honrar sua obrigação, a resilição será evitada. Conseqüentemente, quanto mais o consumidor tardar em denunciar o atraso do profissional, mais esse último disporá de tempo para cumprir seu compromisso. É um tipo de período de graça, deixado à iniciativa do consumidor.

Em contrapartida, a ausência de reação do consumidor no atraso de sessenta dias deve ser interpretada como uma prova do caráter não essencial, aos seus olhos, da obrigação de pontualidade do profissional. Isso não significa que este possa retardar ao infinito o momento em que honrará o contrato. Outro recurso possível ao direito comum de inexecução contratual, compreendendo-lhe eventualmente a resolução judiçiária do artigo 1184 do Código Civil, em caso de falta persistente, mantém-se aberta ao consumidor a via específica da intimação a fazer ${ }^{12}$. Esta supõe que o consumidor conserve um interesse em manter a relação contratual até sua implementação, seja porque ele não conhece outro profissional similar para executar a prestação requerida, seja porque ele sabe que não encontrará condições financeiras tão vantajosas em comparação com um concorrente.

108 Supra, $n^{\circ}$ s Becs.

109 Cf. Paris, 3 de julho de 2001: D. 2001, 2740, obs. RONDEY, para uma entrega em « fins de julho » 2 de outubro de 2003: RJDA $2004, n^{\circ} 152$, para uma entrega «no mais tardar, na segunda quinzena do mês de março».

$110 \mathrm{~V}$. Versailles, 22 de setembro de 2000 : BRDA $2000, \mathrm{n}^{\circ}$ 21, para um atraso de fabricação de um construtor automobilístico julgado « previsivel ». No mesmo sentido, Paris, 21 de janeiro de 1997: Contrats, conc, consom. 1997, n 105, obs. RAYMOND, para um atraso devido a um erro do fabricante.

111 Código do Consumidor, art. L. 114-1, al. 3

112 Código do Consumidor, art. R. 142-2. 
41 - Mas outros atrasos imputáveis aos profissionais não encontram solução na aplicação desses dispositivos específicos. Imaginemos, assim, todas as hipóteses em que, no curso da execução do contrato, o consumidor esteja diante do fato consumado e submerso, imediatamente, em uma situação prejudicial. Como não mencionar o caso particular dos atrasos dos transportadores?

Sem dúvida, no transporte de passageiros, o transportador tem o dever essencial de transportar esses últimos são e salvos ao destino. Mas há também o dever de conduzir-lhes "de acordo com o horário previsto", e ele vincula sua responsabilidade às suas "falhas na obrigação de pontualidade" "113. Tal dever vale, ainda, para todos os tipos de transporte ${ }^{114}$, sendo mesmo qualificado como essencial, no caso em que o transportador publiciza e garante a confiabilidade e a celeridade de seu serviço ${ }^{115}$.

Apesar desses princípios, faz-se necessário reconhecer que o consumidor não será praticamente jamais indenizado por prejuízos de qualquer monta (correspondências e encontros falhos, gastos com hotel e restaurante, custo de outro transporte, mercadorias avariadas ou inutilizáveis em razão de sua entrega tardia...) sofridos pelo atraso.

Naturalmente, convém deixar de lado todas as hipóteses nas quais o atraso do transportador se explique por causas alienígenas ${ }^{116}$ ou, nos casos particulares de transporte de passageiros, por razões de segurança ${ }^{117}$, sendo entendido que compete ao profissional o ônus de provar essas circunstâncias exoneratórias ${ }^{118}$. Por outro lado, sabemos que, seguindo os termos do artigo 1150 do Código Civil, somente os danos previsíveis são reparáveis ${ }^{119}$, além do dolo ou da falta relevante do contratante recalcitrante.

Mas, sobretudo, o direito positivo faz prova de certa leniência com relação aos transportadores como sujeitos de cláusulas limitadoras de responsabilidade inseridas em seus contratos. O princípio de sua validade é efetivamente admitido, salvo no caso em que o dever de pontualidade é considerado essencial ${ }^{120}$ ou, ainda, no caso da falta relevante, dolosa ou inescusável do próprio transportador ${ }^{122}$. Por vezes, também, os juízes admitem que as condições gerais do contrato podem validamente prever que os horários indicados pelo profissional "não fazem parte do contrato"122 ou consideram que a placa publicitária atestando

113 Paris, 4 de outubro de 1996 : JCP G 1997, II, 22810, nota PAISANT et BRUN, no caso dos atrasos da SNCF

114 Nesse sentido, por exemplo, para um transporte terrestre de mercadorias : Cass. com., 2 de abril de $1974:$ Bull. civ. IV, n 122 ; 8 de julho de 2003 , apelo $n^{\circ} 00-17846$, inédito.

115 Ca\&s com, 22 de outubro de 1996 : Bull, civ. IV, n 261 ; Contrats, conc, consom. 1997, n² 24, obs. LEVE-NEUR, D. 1997,121 , nota SÉM AUX;Defre'nois 1997, p. 333, obs. D. MAZEAUD; RTD civ. 1997, e 418, obs. MESTRE. - Câmara Mista, 22 de abril de 2005, 2 esp. : Contrats, cône., consom. 2005, $n^{\circ}$ 150, obs. LEVENEUR;JCP G 2005, II, 10066, nota LOISEAU.

116 Código do Consumidor, art. L. 133-2; p. ex.: Cass. com., 6 févr. 1973 : Bull. civ. IV, n 62

117 G. PAISANT et P. BRUN, note sous Paris, 4 oct. 1996, préc.

118 P. ex. : Cass. com., 13 de janeiro de 1970: Bull civ. IV, nº 17. - 16 de março de 1999, recurso n 97-11428, inédit

119 Cf. Paris, 31 de março de 1994 : D. 1994, inf. rap., 134

120 Cf referências citadas na nota 114 supra; adde, Caen, 5 de janeiro de 1999 , décision $n^{\circ} 963691>$ inédito.

121 P. ex.: Cass. 1 civ., 14 de março de 1995, recurso n 93-10370, inédito. -Ass. plén., 30 de junho de 1998: Bull, civ., ass. plén., n 2. - Cass. 1 civ, 22 de junho de 2004, recurso n ${ }^{\circ}$ 01-00444, inédito.

122 Cass. 1 civ., 5 de julho de 2005, v. Bulletin. 
o estado de regularidade e rapidez do transporte não apresenta "qualquer valor contratual"123; o que é eminentemente contestável.

$\mathrm{Na}$ falta de previsões contratuais especiais ${ }^{124}$, no transporte público de mercadorias, em que se aplicam os dispositivos de um contrato de adesão ${ }^{125}$, a limitação de responsabilidade do transportador é ainda a regra: em caso de atraso prejudicial ao cliente, o transportador é somente obrigado a "verter uma indenização que não exceda o preço do transporte". Acertadamente, no entanto, a Corte de Cassação decidiu que a falta relevante ou dolosa do transportador desnudaria essa limitação de responsabilidade ${ }^{126}$. Em contrapartida, o Conselho de Estado julgou que, mesmo entre profissionais e consumidores, tal limitação não sucumbiria ao golpe das disposições do artigo 132-1 do Código de Consumidor relativamente às cláusulas abusivas. O Conselho estima, efetivamente, que, além da reserva de falta relevante, é sempre possível ao consumidor fazer uma declaração de interesse especial que substituiria essa declaração sobre o limite da indenização no contrato de adesão ${ }^{127}$.

Enfim, o caso do transporte aéreo de passageiros, de bagagens ou de mercadorias, mesmo quando não apresenta um caráter internaciona ${ }^{128}{ }^{12}$, provoca disposições supranacionais, a saber o regramento $\mathrm{CEn}^{\circ} 261 / 2004$ de 11 de fevereiro de 2004 e a Convenção de Montreal de 28 de maio de 1999 aplicável em toda a Comunidade desde 27 de junho de 2004. Emergem desses diplomas dois pontos essenciais:

Em primeiro lugar, essas disposições predominam sobre todos os textos internos que seriam de natureza a opor-se às limitações de responsabilidade que elas estabelecem em proveito dos transportadores, notadamente o artigo L. 132-1 do Código do Consumidor, interditando as cláusulas abusivas.

Em segundo lugar, com a preocupação de melhorar o destino dos passageiros, vítimas de atrasos significativos, o regramento comunitário, em seu artigo $6^{\circ}$, lhes permite obter, em todas as circunstâncias, uma reparação estandartizada e imediata, consistindo, por exemplo, dependendo da conseqüência do atraso, em bebidas, refeições e hospedagens gratuitas, assim como na possibilidade de efetuar, sempre gratuitamente, duas ligações telefônicas. Mas foi ventilada a questão da compatibilidade dessas disposições comunitárias com a Convenção de Montreal. Ora, efetivamente, se esta prevê uma exoneração do transportador, que suportaria o ônus de provar ter tomado "todas as medidas que poderiam razoavelmente impor-se para evitar o dano ou que seria impossível para ele tomá-las", o regramento não oferece qualquer escapatória à companhia aérea. Mas a convenção intemacional se sobrepõe ao direito comunitário derivado, expresso por esse regramento.

Em um julgado de 10 de janeiro de 2006, a Corte de Justiça das Comunidades Européias pronunciou-se em favor da compatibilidade ${ }^{129}$. A Corte considera, efetivamente,

\footnotetext{
123 Cass. com, $1^{\circ}$ de fevereiro de 2005 , recurso $n^{\circ} 03-16773$, inédito.

124 Ou quando a cláusula limitadora de responsabilidade seja sem valor, considerando o caráter essencial da obrigação de pontualidade do transportador.

125 Decreto $n^{\circ}$ 99-269, 6 de abril de 1999 :J0 11 avr. 1999

126 Cass. ch. mixte, 22 avr. 2005 , nota 114 supra.

127 CE, 6 de julho de 2005, Doom : D. 2005,2094, nota DELEBECQUE JCP G 2005, II, 10154, nota DONNAT.

128 Cass. civ., 20 de março de 2001 : Bull civ, $\mathrm{I}, \mathrm{n}^{\circ} 81$

120 Aff. C-344/04, IATA Department for transport, tvuw.curia.eu.intl
} 
que a Convenção de Montreal, na limitação de responsabilidade que estabelece em proveito dos transportadores, quantifica os danos individuais sofridos por cada passageiro em consideração ao motivo de seu deslocamento e sua situação pessoal, enquanto que o regramento comunitário apenas trata da reparação dos prejuízos que sofrem de maneira praticamente idêntica todos os passageiros, vítimas do mesmo atraso. Os dois textos, fixandose em estabelecer as reparações diversas de prejuízos diversos, e cada um deles perseguindo um objeto distinto, o princípio da primazia da convenção internacional acaba não encontrando, então, aplicação.

Isso não impede que, apesar dessa decisão positiva, o passageiro aéreo, vítima de atrasos, deva contentar-se com uma singela consolação e que não possa requisitar uma verdadeira indenização.

42 - Em contrapartida, em uma outra área como aquela do crédito ao consumo, a lei utiliza o tempo de maneira mais desfavorável ao profissional, muito embora em relação a ele não se verifique nada de reprovável, porquanto, pelo contrário, é o consumidor-devedor que não executou suas obrigação conforme acordado.

Com efeito, segundo as disposiç̃ões do artigo L. 311-37 do Código do Consumidor, tal como reformado pela lei de 11 de dezembro de 2001, as ações de cobrança "por ocasião da inadimplência do devedor devem ser formadas dentro de dois anos do evento que lhes deu causa, sob pena de preclusão". Enquanto anteriormente todas as ações que tinham seu fundamento na aplicação dos textos do Código do Consumidor sobre o crédito mobiliário, incluindo aquelas intentadas pelo consumidor contra a instituição de crédito, se encontravam submetidas a esse breve prazo, a partir de então o texto passou a representar um sentido único.

Desse modo, em caso de contestação, por via de ação ou de exceção, acerca da regularidade da oferta preliminar, o consumidor dispõe, a partir de então, do prazo do direito comum da prescrição para tanto, isto é, no caso, o prazo de dez anos do artigo L 1104 do Código Comercial. A vantagem conferida ao consumidor em comparação com o direito anterior é evidente, e não menos evidente é a diferença de tratamento em desfavor do profissional. É somente sobre este que repousa a obrigação de diligência.

43 - Encontramos aqui o espírito geral do direito do consumidor. A vantagem legislativa conferida ao consumidor constitui um "reequilíbrio" destinado a compensar "a disparidade de poder econômico entre o credor e o devedor". ${ }^{130}$. A experiência demonstrara, com efeito, que a disposição igualitária precedente recaía muito freqüentemente em favor das instituições de crédito, uma vez que, passado esse prazo de dois anos, eles se encontravam, em qualquer circunstância, ao abrigo das conseqüências das irregularidades que podiam macular suas ofertas preliminares inicialmente emitidas. $O$ texto era, desse modo, em boa parte, desviado de sua finalidade primeira, qual seja a de evitar que, depois de muitos anos de inércia, a instituição credora, cumulando os juros de mora, reclamasse somas consideráveis do consumidor inadimplente ${ }^{131}$.

\footnotetext{
130 P. FLORÈS e G. BIARDEAU, Réforme du délai de forclusion : vers une restauration du régime de protection de l'emprunteur: D. 2002,876 es. ; X. LAGARDE, Fordusion biennale et crédit à la consommation : JCP E 2202, 1116

131 P. FLORÈS e G. BIARDEAU, art. prec.
} 
Ademais, podemos observar que, notadamente no caso do crédito renovável, a regra do prazo de dois anos ao qual é submetida a ação do credor é atualmente objeto de uma interpretação favorável ao consumidor. Esse prazo transcorre, com efeito, imediatamente "a contar do primeiro vencimento não regularizado" 132 e não mais "a contar do dia no qual a abertura de crédito teve fim" ${ }^{133}$.

O direito do consumidor atribui ao profissional, portanto, também nessa matéria, direta e explicitamente, as obrigações do tempo. Algumas vezes essa obrigação será somente indireta ou implícita.

\section{B - As obrigações resultantes da legislação sobre as cláusulas abusivas}

44 - Se o tempo, da mesma forma que outros elementos, figura entre as previsões contratuais, a expressão dessas últimas encontra um limite na noção de ordem pública e na existência de disposições legislativas ou regulamentares de caráter imperativo.

É nesse sentido que a legislação sobre as cláusulas abusivas, limitando a liberdade do profissional na determinação de estipulações contratuais que ele propõe à sua clientela de consumidores, pode se opor a certas cláusulas de duração ou de prazos, na medida em que elas, seguindo a disposição geral do artigo L. 132-1 do Código do Consumidor, teriam "por objeto ou por efeito criar, em detrimento do não-profissional ou do consumidor, um desequilíbrio significativo entre os direitos e as obrigações das partes no contrato". Essa legislação deveria, pois, dissuadir os profissionais de inserir nos seus contratos cláusulas suscetiveis de serem julgadas abusivas conforme esse critério geral.

Atualmente, nenhuma cláusula de duração ou de prazo é expressamente proibida sob esse fundamento. Podemos citar, provavelmente, os pontos $\mathrm{f}$ e $\mathrm{g}$ do anexo ao artigo L. 132-1. O primeiro se dirige às cláusulas que autorizam "o profissional a pôr fim sem aviso prévio razoável a um contrato de duração indeterminada, salvo no caso de grave motivo.", enquanto que o segundo se refere àquelas que têm por objeto ou por efeito "prorrogar automaticamente um contrato de duração determinada, na ausência de manifestação contrária do consumidor, quando uma data excessivamente distante do término do contrato tenha sido fixada como data limite para expressar essa vontade de não-prorrogação por parte do consumidor". Essas duas cláusulas, porém, do mesmo modo que todas as outras enumeradas nesse anexo legislativo, não são formalmente proibidas; elas "podem" somente "ser consideradas como abusivas se cumprirem as condições previstas pelo mencionado artigo L. 132-1.

É, portanto, somente sob esse prisma vago do "desequilíbrio significativo" que convém se interrogar sobre o caráter abusivo ou não das cláusulas de duração ou de prazo nos contratos de consumo, concluindo-se que uma cláusula considerada como abusiva nas relações entre profissionais e consumidores conservaria todo seu valor e sua eficácia nas outras relações contratuais ${ }^{134}$.

132 Cass ass plen., 6 de junho de 2003: D. 2003, 1905, nota LAGARDE; Contrats, conc, consom. 2003, n. ${ }^{\circ} 132$, obs. RAYMOND

133 Cass. $1^{\text {a }}$ civ., 9 de março de 1999: Bull. civ. I, n. ${ }^{\circ} 85$

134 Por exemplo: Cass com., 23 de novembro de 1999: Bull.cir. IV, n. ${ }^{\circ}$ 210; JCP G 2000, II, 10326, nota CHAZAL; Contrats, conc, consom. $2000,1 .^{\circ} 40$, obs. LEVENEUR; Cass. $3^{\text {a }}$ civ., 28 de outubro de 2003 , recurso n $.^{\circ} 02-13580$, inédito. 


\section{As cláusulas de duração}

45 - Dentre a variedade de cláusulas relativas à duração do contrato, um certo número delas já foi objeto de denúncia por parte da Comissão de Cláusulas Abusivas ${ }^{135}$. Por certo, as recomendações da comissão, do mesmo modo que o anexo ao artigo L. 132-1, não apresentam um caráter normativo. Exatamente nesse sentido se manifestou a Corte de Cassação ${ }^{136}$ : "elas não são geradoras de regras cujo descumprimento leve à possibilidade de cassação". Tal fato não impede que os juízes possam legitimamente fundamentar sobre elas suas decisões ${ }^{137} \mathrm{ou}$ que possam nelas se inspirar. De todo modo, as cláusulas denunciadas pela Comissão se tornam de uma validade incerta e, em caso de litígio, o consumidor tem boas chances de não vê-las aplicadas. Essa chance se encontra hoje reforçada pelo fato de que, em uma decisão de 27 de junho de $2000^{138}$, a CJCE admitiu que "o juiz nacional possa apreciar de ofício o caráter abusivo de uma cláusula de contrato que a ele foi submetida"...; mesmo, portanto, que o próprio consumidor não saiba apreciar esse meio de defesa.

Dentre o conjunto dessas cláusulas de duração, duas demandam mais especialmente a atenção: aquelas que prevêem uma duração inicial e aquelas que, associadas ou não às primeiras, visam a constituir obstáculo à resilição do contrato pelo consumidor.

46 - O princípio que consiste, em um contrato de execução sucessiva, em prever uma duração inicial determinada, sem prejuízo de uma eventual recondução, não é em si contestável. Eventualmente, o próprio consumidor reivindicará a duração da relação contratual. É desse modo que, na recomendação n. ${ }^{\circ} 85-03$, concernente aos contratos propostos pelos estabelecimentos acolhedores de pessoas idosas ${ }^{139}$, a Comissão de Cláusulas Abusivas pôde preconizar a eliminação das cláusulas que têm por objeto ou por efeito, quando o contrato é de duração determinada, "fixá-la em um nível inferior à duração legal dos aluguéis residenciais" ou "permitir ao profissional não renovar o contrato de duração determinada por outros motivos que não sérios e legítimos"... Existem casos, portanto, nos quais a segurança da duração da relação contratual é favorável ao consumidor. A duração mínima aparece, pois, como uma obrigação para o profissional.

Em regra geral, no entanto, é o inverso que se produz: a duração mínima é estipulada no interesse do profissional. Os exemplos são muitos: contratos de assinatura, de manutenção e, mais freqüentemente, os de fornecimento prolongado de bens ou de serviços. Se, em princípio, essa prática não é abusiva, ainda é necessário que essa duração inicial não seja atipicamente extensa. Deve-se julgar contrato por contrato, conforme seu tipo e sua estrutura.

Por exemplo, na recomendação n. ${ }^{\circ}$ 84-01 sobre os contratos de fornecimento de gás de petróleo liquefeito, a Comissão de Cláusulas Abusivas condenou as cláusulas que têm por

\footnotetext{
135 Recomendação n. ${ }^{\circ} 2001-02$ sobre as cláusulas relativas à duração dos contratos concluídos entre profissionais e consumidores: BOCC 23 de maio de 2001.

136 Cass. $1^{2}$ civ., 13 de novembro de 1996. Bull. cuz: I, n. ${ }^{\circ}$ 399; D. 1997, somm. 174, obs. DELEBECQUE; RTD oir: 1997, 791, obs LIBCHABER

137 Cass., $1^{\text {a }}$ civ., 10 de fevereiro de 1998: Bull. ciz: $1, n^{\circ}{ }^{\circ}$ 53; D. 1998, 539, nota MAZEAUD; JCP G 1998, II, 10124, nota PAISANT; Contrats conc, consom. 1998, n. ${ }^{\circ} 70$; RTD ow 1998,674 , obs. MESTRE

138 Aff. C-240/98 à C 244/98, Oreano: Rec. I, 4941, JCP G 2001, II, 10513, nota CARBALLO FIDALGO e PAISANT; RTD av. 2001, 878, obs. MESTRE e FAGES; Petites. Affiches 24 de julho de 2001, p. 25, nota HOURDEAU; RTD com. 2001, 291, obs. LUBY.

139 BOCC de 9 de novembro de 1985
} 
objeto ou por efeito "impor uma duração inicial superior a três anos" ou ainda "permitir ao contrato de manutenção (do reservatório) uma duração superior àquela dos contratos de fornecimento de gás ${ }^{\prime 140}$. $\mathrm{O}$ abuso decorre do fato de que, em razão dessas estipulações, os consumidores são, a rigor, impedidos de pleitearem condições mais vantajosas junto aos profissionais concorrentes ou, ainda, de utilizar outras formas de energia menos onerosas.

Por outro lado, em um contrato de assinatura de telefonia móvel, a duração inicial de um ano não parece em si abusiva, na medida em que ela tem por contrapartida a entrega gratuita ao consumidor, ou mesmo por um preço simbólico, de um aparelho telefônico portátil. Nesse tipo de contrato, o desequilíbrio significativo em detrimento do consumidor se revela quando, de maneira complementar, o contrato prevê que toda resilição antecipada por sua iniciativa torna imediatamente exigiveis as parcelas de assinatura restantes, salvo quando a ruptura é motivada por circunstâncias taxativamente elencadas. O consumidor é, pois, com efeito, dissuadido de resilir o contrato antes do advento do termo inicial, até mesmo quando ele teria motivos perfeitamente legítimos para fazê-lo ${ }^{141}$, como, por exemplo, na hipótese de uma transferência profissional para o exterior. É dessa forma que, em sua recomendação n. ${ }^{\circ}$ 99-02, a Comissão de Cláusulas Abusivas preconizava a supressão das cláusulas que têm por objeto ou por efeito "impor uma duração mínima de doze meses ao contrato, sem permitir ao consumidor a escolha de uma duração diferente e sem prever a possibilidade de uma resilição antecipada por motivo legítimo" ${ }^{142}$. Essa idéia foi retomada pela Comissão, em termos muito próximos, para todos os contratos de consumo, na recomendação n. ${ }^{\circ} 2001-02^{143}$.

47 - Independentemente de qualquer duração inicial mínima, certos contratos propostos aos consumidores tendem a obstaculizar a faculdade de resilição, mesmo quando ela se fundamenta sobre a culpa do profissional. Tenha sido o contrato concluído com duração determinada ou indeterminada, essas estipulações podem ser consideradas como abusivas, uma vez que a manutenção da relação contratual, nessas condições, não permite ao consumidor obter a contraprestação legítima do pagamento ao qual ele se obrigara e tampouco de encontrar satisfação junto a outro profissional. Esse tipo de cláusula já foi denunciado pela Comissão de Cláusulas Abusivas ${ }^{144}$ e anulado repetidas vezes pelos juízes ${ }^{145}$.

140 BOCC 20 de novembro de 1984 ; comp. Versalhes, $3^{\mathrm{a}} \mathrm{ch}$., 5 de maio de 2005 , julgado n. $^{\circ} 265$, que recusou a considerar esse tipo de cláusula como abusiva, quando a duração do contrato resulta de condições particulares, as quais comportam a esse fim uma cláusula deixada em branco, porque ela somente estabelece "o princípio de uma livre negociação". www.clausesabusives.fr/juris.

141 Versalhes, 4 de fevereiro de 2004: D. 2004, 635

142 BOCC 27 de setembro de 1999

143 Recomendação n. ${ }^{\circ} 2001-02$ préc.; no mesmo sentido, Cass. $1^{a}$ civ., 29 de outubro de 2002: Bull. civ. I. n. ${ }^{\circ} 254$; RTD civ. 2003 , 90 , obs. MESTRE e FAGES a propósito de um contrato de tele-vigilância; 26 de outubro de 2004, recurso n. ${ }^{\circ} 02-16636$, inédito, igualmente a propósito de uma tele-vigilância.

144 V. Recomendação 2001-02, prec.

145 Por exemplo: Cass. $1^{2}$ civ., 28 de abril de 1987: Bull. ciz: I, n. ${ }^{\circ}$ 134; D. 1998, 1, nota DELEBECQUE; D. 1987, somm. 455, obs. AUBERT; JCP G 1987, II, 20893, nota PAISANT. 


\section{As cláusulas de prazos}

48 - Sabemos que, nas relações de consumo, as cláusulas de prazo indicativo para a entrega da coisa ou para a execução da prestação de serviços pelo profissional são de agora em diante ilícitas em virtude do Código de Consumidor ${ }^{146}$. A Corte de Cassação tinha anteriormente julgado-as abusivas ${ }^{147}$. Existem, todavia, muitas outras cláusulas relativas aos prazos.

Pensamos inicialmente naquelas que, na ausência de prescrições legais ou a fim de reforçar as obrigações em detrimento dos consumidores, obriga estes últimos a cumprirem certos atos dentro de um prazo determinado, sob pena de serem privados de um direito.

49 - Nesse ponto, ainda, os trabalhos da Comissão de Cláusulas Abusivas oferecem preciosas indicações sobre as estipulações que os profissionais são incitados a eliminar de seus contratos. Ela pôde, dessa forma, denunciar, de maneira geral, as cláusulas que têm por objeto ou por efeito "impor um prazo de prescrição para ingressar em juízo ou reduzir o prazo fixado por lei" ${ }^{148}$. Para o caso de diversos contratos, a Comissão também afastou as cláusulas que "fixam prazos demasiadamente breves para reclamações", as quais pode o consumidor ser levado a fazer ${ }^{149}$, por exemplo, quando da expiração de um contrato, a fim de requerer um reembolso ${ }^{150}$. Nessa mesma linha de entendimento, são regularmente denunciadas as cláusulas que impõem prazos demasiadamente curtos ao consumidor para efetuar a declaração de sinistro ${ }^{151}$.

50 - Freqüentemente contestadas são ainda as cláusulas que, na previsão de resilição de um contrato, estabelecem prazos de aviso prévio que, ou permitem ao profissional de se exonerarem com um mínimo de obrigações ${ }^{152}$, ou, de forma mais ampla, por sua extensão, são de natureza a tornar o consumidor prisioneiro do contrato, uma vez que, por exemplo, este não estará em condições de pôr fim a uma cláusula de recondução tácita.

Ainda que se preocupe dessa questão das reconduções tácitas, a lei de 28 de janeiro de 2005 não traz verdadeiramente uma solução a esse problema preciso. Se, com efeito, o novo artigo L. 136-1 do Código do Consumidor obriga o profissional a informar ao consumidor acerca da possibilidade que lhe é dada de evitar a renovação do contrato, no mínimo três meses antes da data limite contratualmente estipulada ${ }^{153}$, essa disposição não leva em

146 Supra, $\mathrm{n}^{\circ} 40$

147 Cass. $1^{\text {a }}$ civ., 16 de julho de 1987: Bull ar: I, n. ${ }^{\circ} 226$; D. 1988, 49, nota CALAIS-AULOY; JCP G 1988, II, 21001, nota PAISANT

148 Recomendação n. ${ }^{\circ}$ 79-02 sobre as cláusulas concernentes aos recursos na Justiça' BOSP 24 de fevereiro de 1979.

149 Recomendação n. ${ }^{\circ}$ 94-04 concemente aos contratos de locação sazonal: BOCC 27 de outubro de 1994 ; no mesmo sentido, recomendação $n^{\circ}$ 94-03 sobre os contratos de estágio lingúístico: BOCC 27 de setembro de 1994.

150 Recomendação n. ${ }^{\circ}$ 2-01 relativa aos contratos de vendas de catálogos em matéria imobiliária: BOCC 26 de fevereiro de 2002 ; comp. Cass $1^{\mathrm{a}}$ civ., $1^{\circ}$ de fevereiro de 2005: Bull. civ. $\mathrm{I}, \mathrm{n} .{ }^{\circ} 61$, que recusou a considerar como abusiva a cláusula de um contrato de depósito-venda que fixava em quinze dias após a resilição do contrato o prazo a partir do qual o profissional podia se liberar de sua obrigação de restituição em relação ao consumidor depositante

151 Recomendação n. ${ }^{\circ}$ 85-04 sobre os contratos de seguro destinados a cobrir diversos riscos da vida privada: $B O C C 6$ de dezembro de 1985, no mesmo sentido, recomendações n. ${ }^{\circ}$ 89-01: BOCC 14 de julho de 1989, 96 02: BOCC 3 de setembro de 1996; 97-01: BOCC11 de junho de 1997; 02-03: BOCC30 de maio de 2002.

152 Cfr. recomendação n. ${ }^{\circ}$ 85-03 concemente aos contratos propostos pelos estabelecimentos acolhedores de pessoas idosas que, por exemplo, denuncia as cláusulas que permitem ao profissional "resilir um contrato de duração indeterminada por outros motivos que não sétios e legítimos"; adde, pela condenação de uma cláusula que permite a um profissional, em um contrato de fornecimento de acesso à Internet, de risilí-lo unilateralmente "a qualquer momento", sem motivo preciso: Versalhes, $1^{\text {a }} \mathrm{ch}$., 15 de setembro de 2005 , www.clauses-abusives.fr/juris

153 Infra, n. ${ }^{\circ} 35$ es 
consideração as dificuldades surgidas em razão de que, às vezes, a extensão do prazo de aviso prévio imposta ao consumidor não lhe permite decidir no dia em questão de maneira apropriada sobre a pertinência da continuação ou não do contrato. É por isso que o anexo do artigo L.132-1 ${ }^{154}$, da mesma forma que as proposições da Comissão de Cláusulas Abusivas relativas às cláusulas que têm por objeto ou por efeito "constranger o consumidor, para evitar a prorrogação ou a recondução tácita de um contrato de duração determinada, a notificar sua intenção ao profissional em uma data excessivamente afastada do advento do termo" 155 nada perderam em termos de atualidade.

Notemos, ainda, que, de uma maneira geral, nos contratos de duração indeterminada, a Comissão recomenda que o prazo de aviso prévio anterior à resilição não seja mais extenso ao consumidor do que para o profissional ${ }^{156}$.

51. - Por fim, as cláusulas de consentimento implícito são algumas vezes estipuladas ao encontro do consumidor, que terá deixado correr um certo prazo sem manifestar oposição a uma informação ou uma proposição recebida pelo profissional. De maneira geral ${ }^{157}$ ou especial $^{158}$, elas são igualmente denunciadas pela Comissão de Cláusulas Abusivas.

De toda forma, de modo bastante surpreendente, a solução contrária prevalece nas relações bancárias, ainda que os bancos se encontrem em uma situação de evidente superioridade econômica e técnica em relação a sua clientela de consumidores. Dessa maneira, é admitido na jurisprudência que o silêncio do cliente, mesmo do não-comerciante, represente a aprovação da prestação de contas que lhe foi dirigida" ${ }^{159}$; a própria lei ${ }^{160}$ dispõe que "na ausência de contestação pelo cliente dentro do prazo de dois meses", após a comunicação do projeto de modificação das condições tarifárias do banco, "é presumida a aceitação da nova tarifa".

Talvez seja o mais correto, porque essa situação é a tal ponto atípica que foi necessária uma lei particular para admiti-la em proveito dos bancos...

52 - "Os dias são talvez iguais para os relógios, porém não para os homens". A fórmula de Marcel Proust ${ }^{161}$ poderia também servir para ilustrar as relações contratuais entre profissionais e consumidores. O tempo não apresenta o mesmo valor jurídico para uns do que para os outros.

Essa desigualdade no que concerne ao tempo, contudo, sem qualquer paradoxo, é destinada somente a restabelecer uma igualdade concreta ${ }^{162}$ em relações estruturalmente desequilibradas. Uma desigualdade de direito para uma igualdade de fato. A problemática não é nova e ultrapassa amplamente os limites do direito do consumidor: aqui como em outros lugares, ela é fortemente impregnada pela relatividade, uma relatividade que muito convêm ao tempo.

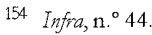

155 Recomendação n ${ }^{\circ} 2001-02$ sobre as cláusulas relativas à duração dos contratos concluídos entre profissionais e consumidores: BOCC 23 de maio de 2001.

156 Recomendação prec.

157 Recomendação n. ${ }^{\circ}$ 94-01 concennente às cláusulas chamadas de consentimento implícito: BOCC 27 de setembro de 1994

158 Recomendações $n{ }^{\circ}$ 85-02 concernente aos contratos de compra de vé́culos automóveis de turismo: $B O C C 4$ de setembro de 1985 e $99-02$ relativa aos contratos de radio telefones portáteis: BOCC 27 de setembro de 1999

159 Cass. com., 17 de março de 1981: Bull. cir: IV, n. ${ }^{\circ} 112$. - 10 de maio de 1994: Bull. civ. IV, n. ${ }^{\circ} 170$

160 Código Monetário., art. L. 312-1-1, e decisão de 8 de março de 2005, art. 2,7º 7016 de março de 2005, p. 4494.

161 Crônicas, Vacanas de Pâques, Le Figgaro, 25 de março de 1913

162 O. LITTY, op. cit.
} 